\title{
Last Works
}




\section{A L S O B Y M A R K C T A Y O R}

Speed Limits: Where Time Went and Why We Have So Little Left

Recovering Place: Reflections on Stone Hill

Rewiring the Real: In Conversation with William Gaddis, Richard Powers, Mark

Danielewski, and Don DeLillo

Refiguring the Spiritual: Beuys, Barney, Turrell, Goldsworthy

Crisis on Campus: A Bold Plan for Reforming Our Colleges and Universities

Field Notes from Elsewhere: Reflections on Dying and Living

After God

Mystic Bones

Confidence Games: Money and Markets in a World without Redemption

Grave Matters (with Dietrich Christian Lammerts)

The Moment of Complexity: Emerging Network Culture

About Religion: Economies of Faith in Virtual Culture

The Picture in Question: Mark Tansey and the Ends of Representation

Critical Terms for Religious Studies

Hiding

Imagologies: Media Philosophy (with Esa Saarinen)

The Réal: Las Vegas, Nevada (with Jose Marquez)

Nots

Disfiguring: Art, Architecture, Religion

Michael Heizer: Double Negative

Tears

Altarity

Deconstruction in Context: Literature and Philosophy

Erring: A Postmodern A/Theology

Deconstructing Theology

fourneys to Selfhood: Hegel and Kierkegaard

Unfinished . . . Essays in Honor of Ray L. Hart

Religion and the Human Image (with Carl Raschke and James Kirk)

Kierkegaard's Pseudonymous Authorship: A Study of Time and the Self 


\section{Last Works \\ Lessons in Leaving}

Mark C. Taylor

Yale

UNIVERSITY PRESS

New Haven \& London 


\section{Copyright (C) 2018 by Mark C. Taylor.}

All rights reserved.

This book may not be reproduced, in whole or in part, including illustrations, in any form (beyond that copying permitted by Sections 107 and 108 of the U.S. Copyright Law and except by reviewers for the public press), without written permission from the publishers.

Yale University Press books may be purchased in quantity for educational, business, or promotional use. For information, please e-mail sales.press@yale.edu (U.S. office) or sales@yaleup.co.uk (U.K. office).

Set in Bulmer type by Westchester Publishing Services. Printed in the United States of America.

Library of Congress Control Number: 2017940587

ISBN 978-0-300-22439-9 (hardcover : alk. paper)

A catalogue record for this book is available from the British Library.

This paper meets the requirements of ANSI/NISO Z39-48-1992 (Permanence of Paper).

$$
\begin{array}{llllllllll}
10 & 9 & 8 & 7 & 6 & 5 & 4 & 3 & 2 & 1
\end{array}
$$


For

Fackson Noel

Taylor Virginia

Selma Linnea

Elsa Ingrid 
The great thing is to last and get your work done and see and hear and learn and understand; and write when there is something that you know; and not before; and not too damned much after. Let those who want to save the world if you can get to see it clear as a whole. Then any part you make will represent the whole if it is made truly.

-Ernest Hemingway, Death in the Afternoon 